\title{
Phytophthora spp. Associated with Forest Soils in Eastern and North-Central U.S. Oak Ecosystems
}

\author{
Y. Balci, S. Balci, J. Eggers, and W. L. MacDonald, West Virginia University, Division of Plant and Soil Sciences, \\ 1090 South Agricultural Sciences Building, Morgantown 26506; J. Juzwik, United States Department of Agriculture \\ (USDA) Forest Service, Northern Research Station, St. Paul, MN 55108; R. P. Long, USDA Forest Service, North- \\ ern Research Station, Delaware, $\mathrm{OH}$ 43015; and K. W. Gottschalk, USDA Forest Service, Northern Research Sta- \\ tion, Morgantown, WV 26505
}

\begin{abstract}
Balci, Y., Balci, S., Eggers, J., MacDonald, W. L., Juzwik, J., Long, R. P., and Gottschalk, K. W. 2007. Phytophthora spp. associated with forest soils in eastern and north-central U.S. oak ecosystems. Plant Dis. 91:705-710.

A survey of soils associated with oak species was conducted in 2003 and 2004 in Indiana, Illinois, Maryland, Michigan, Minnesota, Pennsylvania, Ohio, West Virginia, and Wisconsin to investigate the occurrence of Phytophthora spp. Soils taken from around the base of healthy and declining oak trees were flooded with $\mathrm{H}_{2} \mathrm{O}$ and Quercus robur leaflets were used as bait for Phytophthora spp. From 829 soil samples collected near trees, 21\% were positive for Phytophthora spp., with 55\% of the 125 sites surveyed yielding a Phytophthora sp. Phytophthora cinnamomi was the most frequently isolated species, representing $69.4 \%$ of the Phytophthorainfested sites surveyed. Other species, in decreasing order of isolation frequency were Phytophthora sp. 2, P. citricola, P. europaea, P. cambivora, P. quercina-like isolates, and Phytophthora sp. 1. No significant association was found between the presence of Phytophthora organisms and site characteristics such as latitude, elevation, soil $\mathrm{pH}$, or the crown condition of the trees. However, in $P$. cinnamomi-infested sites, a significant association was found with the deteriorating crown status of $Q$. alba and the presence of $P$. cinnamomi. The absence of $P$. cinnamomi above the $40^{\circ} \mathrm{N}$ latitude range also was noteworthy.
\end{abstract}

Additional keywords: oak decline, Phytophthora cinnamomi

Studies of the role that Phytophthora spp. play in forest health and their existence in diverse ecosystems have been the focus of research during recent decades. Surveys in many forest ecosystems have demonstrated the existence of a variety of Phytophthora spp. $(3,4,19,24,31,33,35,49)$. Interest in Phytophthora organisms has intensified because of the destructive impact they caused to the native vegetation in areas where they have been introduced and become established. Examples include the introduction of Phytophthora cinnamomi Rands in Australia, Mexico, Spain, and Portugal $(10,44,47)$; the impact of $P$. lateralis Tucker \& Milbrath on Port Orford cedar (Chamaecyparis lawsoniana (A. Murray bis) Parl.) in western North America (25); and the invasion of $P$. ramorum Werres, De Cock \& Man in't Veld in California woodlands and southwest Oregon, with its accompanying impact on the plant nursery industry in the United States and

Corresponding author: Y. Balci

E-mail:YiBalci@mail.wvu.edu

Accepted for publication 3 January 2007.

doi:10.1094/PDIS-91-6-0705

(C) 2007 The American Phytopathological Society
Europe $(17,18,22,40)$. Studies of these problems also have led to the discovery of new species and distributions. During the course of oak decline studies in Europe, five new species of Phytophthora were found, including $P$. europaea E. M. Hansen \& T. Jung, $P$. pseudosyringae T. Jung \& Delatour, P. psychrophila E. M. Hansen \& T. Jung, $P$. quercina T. Jung, and $P$. uliginosa E. M. Hansen \& T. Jung (34-36). Other previously unknown species discovered include $P$. nemorosa E. M. Hansen and Reeser from mixed-hardwood forests of the central coast of California and southwestern Oregon (26). Likewise, $P$. kernoviae Brasier, Beales, and S. A. Kirk is associated with bleeding stem lesions of forest trees and foliar necrosis of ornamentals in the United Kingdom (9).

The existence of native or exotic species of Phytophthora in soils of eastern and central U.S. oak ecosystems is largely unknown. This lack of information and the potential threat of $P$. ramorum to eastern oak species provided the impetus for this study. The objective was to conduct isolations from soils sampled across a broad geographic range of oak and related forest types to provide baseline information on Phytophthora spp. that are associated with oak forest ecosystems in the eastern United States. Relationships among geographic locations, elevation, soil $\mathrm{pH}$, and decline status of oak trees were evaluated with respect to the incidence of Phytophthora spp. that were isolated.

\section{MATERIALS AND METHODS}

Field study. Soils were sampled in Illinois (IL), Indiana (IN), Maryland (MD), Michigan (MI), Minnesota (MN), Ohio $(\mathrm{OH})$, Pennsylvania (PA), Wisconsin (WI), and West Virginia (WV). Soils were sampled in spring 2004 (May to July) and fall 2004 (September to November). A few sites in MD and WV also were sampled in fall 2003. In each state, eight sites usually were sampled during the spring and fall periods. When possible, half of the sites were chosen from declining and half from nondeclining stands. Crown status of trees was assessed as follows: class 1, no symptoms of decline, crown transparency less then 10 to $15 \%$; class 2, slight damage, dieback of some branch tips and small gaps in the lateral branch system of the crown, crown transparency 15 to $35 \%$; class 3, moderate damage, apparent transparency in all parts of the crown, dieback of twigs and branches and large gaps in the lateral branch system, yellowing and wilting of leaves, epicormic shoots often present, crown transparency 35 to $55 \%$; and class 4 , severe damage, considerable transparency of crown and many large gaps, many dead twigs and branches, leaves mainly restricted to shoot tips, yellowing of leaves and many epicormic shoots, crown transparency 55 to $75 \%(3,4)$. Sites were chosen to avoid areas impacted by recent storm damage, major defoliation, or oak wilt caused by Ceratocystis fagacearum (T. W. Bretz) J. Hunt. Although most stands contained a diverse population of tree species, oak generally predominated. Trees were greater than 40 years of age and most were 70 to 100 years old. In each state, sampling sites were identified with respect to oak forest types and were distributed as much as possible among these different types. At each site, four soil subsamples were taken in cardinal directions and at a distance of 1 to $1.5 \mathrm{~m}$ from the base of each selected tree. After removing the organic layer, soils were sampled down to a depth of about $30 \mathrm{~cm}$. The four subsamples were bulked to produce a total sample of approximately $2 \mathrm{~kg}$. Generally, 
five trees were sampled per site. When no Phytophthora spp. were isolated during spring sampling, the same site was resampled in fall; however, different oak trees were sampled. Soil $\mathrm{pH}$ was measured for each composite soil sample using a 3:1 mix of soil and $0.011 \mathrm{CaCl}_{2}\left(=\mathrm{pH}\left[\mathrm{CaCl}_{2}\right]\right)$ or distilled water $\left(=\mathrm{pH}\left[\mathrm{H}_{2} \mathrm{O}\right]\right)$ and measured on a Thermo Orion $\mathrm{pH}$ meter.

Isolation. In the laboratory, each sample was mixed thoroughly; a single 250-g subsample was flooded with $500 \mathrm{ml}$ of distilled water and baited by floating 3- to 7-day-old Quercus robur leaflets (32). Baited samples were kept at temperatures of 17 to $20^{\circ} \mathrm{C}$. After 3 to 5 days, discolored leaf samples were examined microscopically $(\times 200)$ and those with sporangia typical of Phytophthora spp. were plated on PARPNH selective medium (V8 juice agar [V8A] media amended with pimaricin at $10 \mu \mathrm{g} / \mathrm{liter}$, ampicillin at $200 \mu \mathrm{g} / \mathrm{liter}$, rifampicin at $10 \mu \mathrm{g} / \mathrm{ml}$, pentachloronitrobenzene [PCNB] at $25 \mu \mathrm{g} /$ liter, nystatin at $50 \mu \mathrm{g} /$ liter, and hymexazol at $50 \mu \mathrm{g} / \mathrm{liter})$ to establish cultures $(3,4)$. When initial isolation attempts failed, soils were dried at room temperature for 2 weeks and the isolation method was repeated using the same protocol. Soil samples from IN, MD, $\mathrm{OH}, \mathrm{PA}$, and $\mathrm{WV}$ were processed at West Virginia University (WVU) and those from IL, MI, MN, and WI were processed at the United States Department of Agriculture
(USDA) Forest Service laboratory in St. Paul, MN using the same procedure described above. Randomly chosen soil samples were exchanged between laboratories to compare isolation results.

Identification. Isolates were identified to species using morphological features by comparing them with authenticated isolates and species descriptions (20). For morphological identification, the following features were measured: size and type of sporangia, oogonia, antheridia, chlamydospore production, occurrence of hyphal swellings, colony morphology on potatodextrose agar (PDA), and growth rate on V8A. Heterothallic isolates were crossed with known mating types of $P$. cinnamomi and $P$. cambivora. Representative isolates also were identified at the Pennsylvania State University, Department of Plant Pathology (Y. Balci and S. Kang, unpublished data). This was done by sequencing the internal transcribed spacer region of the rDNA and comparing the sequences with those in GenBank using BLAST searches. The sequence data and cultures of representative isolates have been deposited at GenBank and at the American Type Culture Collection, respectively (Table 1).

Data analysis. The relationship between the existence of Phytophthora spp. and decline status of oak trees as well as the latitude was analyzed using logistic regression analyses and tested in a contingency table using Fisher's exact test. The differences of $\mathrm{pH}$ and elevation in Phytophthora spp.-infested and free sites were tested using two-tailed Student $t$ tests. Analyses of all data were performed using the software program JMP 5.0 (43).

\section{RESULTS}

Seven Phytophthora spp. were isolated from $69(55 \%)$ of the 125 sites that were included in the spring and fall sampling periods (Tables 1 and 2). The spring sampling period yielded twice the number of Phytophthora isolations as the fall period (Table 2). In all, 36 sites where no Phytophthora spp. were isolated in the spring period were resampled in the fall; of those, 9 sites yielded Phytophthora spp. Soils surrounding 829 trees were sampled and $171(21 \%)$ yielded a Phytophthora isolate (Table 2). Usually, Phytophthora spp. were obtained on the first isolation attempt, although $23(13.5 \%)$ additional isolations were made as a result of the second baiting routine. All of the $P$. quercina-like isolates and about one-third (five isolates) of Phytophthora sp. 2 were isolated during the second baiting. Generally, one species was isolated from a site. However, two species were isolated at five sites and three species were isolated at three sites. A single species generally was isolated from each soil sample, except on five occasions, when two species were isolated. For soil samples

Table 1. Information on representative isolates

\begin{tabular}{|c|c|c|c|c|c|c|}
\hline Isolate & Phytophthora spp. & Oak species & $\begin{array}{l}\text { Sampled } \\
\text { from }\end{array}$ & Geographic coordinates and state ${ }^{a}$ & $\begin{array}{c}\text { GenBank } \\
\text { accession no. }\end{array}$ & ATCC no. ${ }^{b}$ \\
\hline $\mathrm{OH} 4 / 4$ & Phytophthora cambivora & Quercus velutina & Forest soil & $\mathrm{N} 81^{\circ} 26^{\prime} 0.1^{\prime \prime} ;$ E $39^{\circ} 54^{\prime} 36^{\prime \prime}, \mathrm{OH}$ & EF032478 & MYA-4089 \\
\hline WV Gr1/1 & P. cinnamomi & Q. rubra & Forest soil & N $39^{\circ} 40^{\prime} 22^{\prime \prime}$; E $79^{\circ} 46^{\prime} 20.3^{\prime \prime}$, WV & EF032480 & MYA-4085 \\
\hline $\mathrm{OH} 6 / 5$ & P. citricola & Q. rubra & Forest soil & $\mathrm{N} 84^{\circ} 3^{\prime} 52.8^{\prime \prime} ;$ E $39^{\circ} 29^{\prime} 24^{\prime \prime}, \mathrm{OH}$ & EF032477 & MYA-4087 \\
\hline BM $1 / 10$ & P. europaea & Q. alba & Forest soil & N $38^{\circ} 36^{\prime} 03^{\prime \prime}$; E $79^{\circ} 35^{\prime} 24.3^{\prime \prime}$, WV & DQ313222 & MYA-4088 \\
\hline MN 023 & P. quercina-like & Q. rubra & Forest soil & $\mathrm{N} 93^{\circ} 33^{\prime} 10.5^{\prime \prime}$; E $45^{\circ} 26^{\prime} 14.1^{\prime \prime}, \mathrm{MN}$ & DQ313224 & MYA-4090 \\
\hline WV BSC $1 / 3$ & Phytophthora sp. 1 & Q. rubra & Forest soil & $\mathrm{N} 38^{\circ} 17^{\prime} 10^{\prime \prime} ; \mathrm{E} 79^{\circ} 58^{\prime} 31.1^{\prime \prime}$, WV & EF032479 & MYA-4091 \\
\hline MD $9 / 2$ & Phytophthora sp. 2 & Q. rubra & Forest soil & $\mathrm{N} 78^{\circ} 24^{\prime} 26.7^{\prime \prime}$; E $39^{\circ} 42^{\prime} 0^{\prime \prime}$, MD & DQ313223 & MYA-4086 \\
\hline
\end{tabular}

a $\mathrm{OH}=$ Ohio, $\mathrm{WV}=$ West Virginia, $\mathrm{MN}=$ Minnesota, and MD = Maryland.

${ }^{\mathrm{b}}$ American Type Culture Collection.

Table 2. Assemblage and isolation frequencies of Phytophthora spp. in each state during spring and fall 2004

\begin{tabular}{|c|c|c|c|c|c|c|c|c|c|}
\hline \multirow[b]{2}{*}{$\underline{\text { State }}$} & \multicolumn{2}{|c|}{ Sites sampled } & \multicolumn{2}{|c|}{ Positive sites } & \multicolumn{2}{|c|}{$\begin{array}{l}\text { Soil samples } \\
\text { assayed }\end{array}$} & \multicolumn{2}{|c|}{$\begin{array}{l}\text { Positive soil } \\
\text { samples }\end{array}$} & \multirow[b]{2}{*}{ Phytophthora spp. } \\
\hline & Total & $\mathbf{S} / \mathbf{F}$ & Total & $\mathbf{S} / \mathbf{F}$ & Total & $\mathbf{S} / \mathbf{F}$ & Total & $\mathbf{S} / \mathbf{F}$ & \\
\hline Illinois & 10 & $10 /-$ & 1 & $1 /-$ & 50 & $50 /-$ & 1 & $1 /-$ & Phytophthora citricola, $\mathrm{S}$ \\
\hline Indiana & 14 & $8 / 6(2)^{\mathrm{b}}$ & 9 & $6 / 3$ & 80 & $40 / 40$ & 30 & $20 / 10$ & P. cinnamomi, $\mathrm{S}, \mathrm{F} ;$ P. citricola, $\mathrm{F}$ \\
\hline Maryland & 16 & $14 / 2(5)$ & 10 & $7 / 3$ & 106 & $71 / 35$ & 19 & $14 / 5$ & P. cinnamomi, S,F; Phytophthora sp. $2, \mathrm{~S}$ \\
\hline Michigan & 8 & $6 / 2(6)$ & 0 & $-1-$ & 70 & $30 / 40$ & - & $-1-$ & - \\
\hline Minnesota & 9 & 8/1 (7) & 3 & $2 / 1$ & 80 & $40 / 40$ & 7 & $3 / 4$ & P. europaea, $\mathrm{F} ;$ P. quercina-like, $\mathrm{S}$ \\
\hline Ohio & 14 & $8 / 6(1)$ & 11 & $6 / 5$ & 75 & $40 / 35$ & 25 & $16 / 8$ & $\begin{array}{l}\text { P. cinnamomi, S,F; P. citricola, } \mathrm{S}, \mathrm{F} ; \\
\text { Phytophthora } \text { sp. } 2, \mathrm{~S}, \mathrm{~F} ; \text { P. cambivora, } \mathrm{S}, \mathrm{F}\end{array}$ \\
\hline Pennsylvania & 9 & $8 / 1(7)$ & 5 & $2 / 4$ & 80 & $40 / 40$ & 8 & $3 / 5$ & $\begin{array}{l}\text { P. cinnamomi, S,F; P. europaea, } \mathrm{F} ; \\
\text { P. cambivora, S,F; Phytophthora sp. } 2, \mathrm{~S}\end{array}$ \\
\hline Wisconsin & 11 & $8 / 3(5)$ & 4 & $3 / 1$ & 80 & $40 / 40$ & 4 & $3 / 1$ & $\begin{array}{l}\text { P. quercina-like, S; P. europaea, } \mathrm{S} ; \\
\text { Phytophthora sp. } 2, \mathrm{~S}, \mathrm{~F}\end{array}$ \\
\hline West Virginia & 34 & $28 / 6(3)$ & 26 & $22 / 6$ & 208 & $163 / 45$ & 77 & $57 / 20$ & $\begin{array}{l}\text { P. cinnamomi, S,F; P. citricola, F; P. europaea, F; } \\
\text { Phytophthora sp. } 1, \mathrm{~F} ; \text { Phytophthora } \mathrm{sp} .2, \mathrm{~S}, \mathrm{~F}\end{array}$ \\
\hline Total & 125 & $98 / 63$ & $69(55 \%)$ & $48 / 23$ & 829 & $514 / 315$ & $171(21 \%)$ & $116 / 54$ & $\ldots$ \\
\hline
\end{tabular}

${ }^{a}$ Data are number of samples; $\mathrm{S}=$ spring and $\mathrm{F}=$ fall sampling periods.

${ }^{\mathrm{b}}$ Number in parentheses indicates the number of spring sampling sites that resulted in no Phytophthora recovery and, thus, were resampled in the fall sampling period. 
containing more than one species of Phytophthora, the colonies of different species were different in morphology on the selective medium, and were subcultured onto V8A. No Phytophthora spp. were isolated from the Michigan soil samples. Several sites in Illinois, Minnesota, and Wisconsin also gave low isolation frequencies (Table 2).

Soil samples exchanged between laboratories gave a different result for only one soil sample, where Phytophthora sp. 2 was isolated at the WVU lab but not at the Minnesota lab.

P. cinnamomi was the most commonly isolated species. It was isolated from $69.4 \%$ of the positive sites and represented $73.4 \%$ of Phytophthora isolates (Table 3). $P$. cinnamomi was not isolated from sites in IL, MI, MN, or WI. This species was only isolated at sites below $40^{\circ} \mathrm{N}$ latitude (Fig. 1). When crossed with tester strains, all of the P. cinnamomi isolates proved to be the A2 mating type. Additional sampling in Kentucky (KY) at two oak sites during spring 2005 also yielded isolates of P. cinnamomi (Fig. 1).

The second most common species isolated was Phytophthora sp. 2. This species was isolated from $16.7 \%$ of the sites that yielded Phytophthora spp. and represented $8 \%$ of all isolates (Table 3 ). It occurred over a wide geographical area, including sites in MD, OH, PA, WI, and WV (Fig. 1). Phytophthora sp. 2 did not correspond to any previously described species.

$P$. citricola Sawada, the third most common Phytophthora sp. isolated, was associated with $11.1 \%$ of the sites that yielded Phytophthora spp. in four states (IL, IN, OH, and WV) and represented $5.2 \%$ of isolates (Fig. 1; Tables 2 and 3). The fourth most common species was $P$. europaea. This species was isolated from MN, PA, WI, and WV (Fig. 1; Tables 2 and 3). P. europaea was commonly isolated in the fall and only once in the spring sampling period from a WI site. $P$. cambivora (Petri) Buisman was the fifth most frequently represented species and was only isolated in $\mathrm{OH}$ and PA (Fig. 1; Tables 2 and 3). Among the isolates of this species, four were identified as the A2 mating type and three were identified as the A1 mating type.

Four isolates were identified tentatively as $P$. quercina-like because their sequence data was closest to $P$. quercina. However, they differed from $P$. quercina culturally in oogonial features, growth pattern on PDA, and much slower growth rate. $P$. quercinalike isolates were isolated only during the spring sampling period from sites in $\mathrm{MN}$ and WI and only following a second baiting procedure after soils had been air dried and reflooded.

A seventh isolate, designated Phytophthora sp. 1, matched the sequence data of $P$. europaea. Its morphology differed from $P$. europaea isolates by having smaller globose oogonia with no tapered bases, a different growth pattern on PDA, and different optimum and maximum temperature limits for growth. This isolate will be analyzed further to classify it into appropriate taxa. The Phytophthora sp.1 isolate was found only once in a fall sampling period from WV (Table 2).

$P$. cinnamomi was isolated more frequently from soils associated with $Q$. alba $(27 \%)$ and $Q$. montana (32\%) than from soils surrounding the other oak species. The soils associated with $Q$. rubra were the most commonly sampled, and yielded the most diverse group of Phytophthora organisms. However, P. cinnamomi was associated with only $10 \%$ of the samples from Q. rubra. No Phytophthora spp. were isolated from soils from around $Q$. stellata and $Q$. falcata, although relatively few trees of these species were sampled.

In total, soils around 461 healthy trees and 368 declining trees were sampled. Among the 171 Phytophthora-infested soil samples, Phytophthora spp. were found from soils collected around 95 healthy trees and from 76 declining trees. For the infested sites, there was no significant association between the presence or absence of Phytophthora spp. and the decline status of trees (Fisher's exact test, $P=$ 1.000). However, at sites infested with $P$. cinnamomi, there was a significant association with the presence of $P$. cinnamomi and declining $Q$. alba trees (Fisher's exact test, $P=0.013, R R=1.82,95 \% \mathrm{CI}=1.06$

Table 3. Isolation frequencies of Phytophthora spp. from soil in relation to associated oak species and percent of Phytophthora spp. in Phytophthora-infested sites

\begin{tabular}{|c|c|c|c|c|}
\hline \multirow[b]{2}{*}{ Phytophthora spp. } & \multirow[b]{2}{*}{ Quercus spp. ${ }^{\mathrm{a}}$} & \multicolumn{2}{|c|}{ Number of positive trees } & \multirow[b]{2}{*}{ Percent } \\
\hline & & Total & Spring/fall & \\
\hline \multirow[t]{5}{*}{ P. cinnamomi } & Quercus alba & 48 & $32 / 16$ & 69.4 \\
\hline & Q. coccinea & 3 & $1 / 2$ & \\
\hline & Q. montana & 26 & $21 / 5$ & \\
\hline & Q. rubra & 35 & $27 / 8$ & \\
\hline & Q. velutina & 15 & $10 / 5$ & \\
\hline \multirow[t]{5}{*}{ Phytophthora sp. 2} & Q. macrocarpa & 1 & $1 /-$ & 16.7 \\
\hline & Q. phellos & 1 & $-/ 1$ & \\
\hline & Q. platanoides & 1 & $1 /-$ & \\
\hline & Q. rubra & 9 & $4 / 5$ & \\
\hline & Q. velutina & 2 & $2 /-$ & \\
\hline \multirow[t]{4}{*}{ P. citricola } & $\widetilde{Q} \cdot a l b a$ & 2 & $1 / 1$ & 11.1 \\
\hline & Q. coccinea & 1 & $1 / 0$ & \\
\hline & Q. muehlenbergii & 1 & $1 /-$ & \\
\hline & Q. rubra & 5 & $3 / 2$ & \\
\hline \multirow[t]{4}{*}{ P. europaea } & Q. alba & 3 & $3 /-$ & 8.3 \\
\hline & Q. phellos & 1 & $-/ 1$ & \\
\hline & Q. rubra & 7 & $3 / 4$ & \\
\hline & Q. velutina & 2 & $-/ 2$ & \\
\hline \multirow[t]{5}{*}{ P. cambivora } & Q. alba & 1 & $1 /-$ & 6.9 \\
\hline & Q. muehlenbergii & 1 & $1 /-$ & \\
\hline & Q. palustris & 1 & $-/ 1$ & \\
\hline & Q. rubra & 2 & $2 /-$ & \\
\hline & Q. velutina & 2 & $1 / 1$ & \\
\hline \multirow[t]{2}{*}{ P. quercina-like } & Q. ellipsoidalis & 1 & $1 /-$ & 4.2 \\
\hline & Q. rubra & 3 & $3 /-$ & \\
\hline Phytophthora sp. 1 & Q. rubra & 1 & $-/ 1$ & 1.4 \\
\hline Total & $\ldots$ & 175 & $120 / 55$ & $\ldots$ \\
\hline
\end{tabular}

${ }^{a}$ Total number of oak species sampled were as follows; 175 Q. alba, 18 Q. coccinea, 20 Q. ellipsoidalis, 15 Q. macrocarpa, 81 Q. montana, 5 Q. muehlenbergii, 1 Q. phellos, 3 Q. palustris, 1 Q. platanoides, 382 Q. rubra, and 124 Q. velutina. to 3.15). This association was not found for $Q$. rubra (Fisher's exact test, $P=$ 0.086 ) or $Q$. montana (Fisher's exact test, $P=1.000)$.

Phytophthora organisms were isolated 3.7 to 7.4 (3.2 to 7.1 for $\left.\mathrm{pH}\left[\mathrm{CaCl}_{2}\right]\right)$ and from elevations ranging from 11 to 1,119 $\mathrm{m}$. When elevations among Phytophthorainfested and Phytophthora-free sites were compared, considering all Phytophthora spp., there was no significant difference in the means of elevations $(t=0.593, P=$ 0.554). Likewise, no significant difference existed considering only $P$. cinnamomiinfested sites and elevation $(t=0.940, P=$ $0.349)$. No significant differences were Phytophthora-infested (5.1) and Phytophthora-free (5.04) sites $(t=0.782, P=$ $0.435)$. This also was true when $\mathrm{pH}\left(\mathrm{H}_{2} \mathrm{O}\right)$ of $P$. cinnamomi-infested sites was compared with $P$. cinnamomi-free sites $(t=$ -1.916, $P=0.056)$. The absence of $P$. cinnamomi above $40^{\circ} \mathrm{N}$ latitudes was significant (Fisher's exact test, $P<0.001$ ) (Fig. $1)$, but no significant difference existed among the other Phytophthora spp. with respect to the $40^{\circ} \mathrm{N}$ latitude range (Fisher's exact test, $P=1.000)$. $P$. cinnamomi was found in only one location in Pennsylvania above the $40^{\circ} \mathrm{N}$ latitude range (Fig. 1).

\section{DISCUSSION}

Results of this study provide the first record of the broad range of Phytophthora from soils that ranged in $\mathrm{pH}\left(\mathrm{H}_{2} \mathrm{O}\right)$ from found for the mean $\mathrm{pH}\left(\mathrm{H}_{2} \mathrm{O}\right)$ values of 
spp. that are associated with oak forest soils in the eastern and central United States. Study of oak forest soils in Europe yielded similar isolation frequencies, with about half of the sites yielding a Phytophthora sp. $(3,4,19,27,31,33,49)$. Thus, Phytophthora spp. appear to be common soil inhabitants in these oak ecosystems. The higher isolation rate achieved in the spring sampling probably was due to the more favorable soil moisture and temperatures for the organism during this period of the year. In Australian forests, higher inoculum levels of $P$. cinnamomi were found in spring and early summer (51). The successful recovery of Phytophthora organisms in about one-third of the resampled sites and from $13.5 \%$ of soil isolations after the second baiting routine suggests the need for sampling throughout the year and a repeated isolation routine for a single soil sample to avoid false negative results on sites or soils initially assessed as Phytophthora free. Furthermore, to enhance detection, repeated isolation attempts are required for some species of Phytophthora such as $P$. quercina $(3,4)$ and $P$. cactorum (Lebert \& Cohn) J. Schröt. (29), because recovery was enhanced by repeated flood- ing after soils have been air dried. That also was true for $P$. quercina-like isolates which were isolated after the second baiting attempt in this study.

The frequent recovery of $P$. cinnamomi in our study corresponds with surveys conducted in the southeastern United States $(13,53,55)$. The differences in species assemblage with those studies involves the occurrences of $P$. cactorum and $P$. heveae. The species that were isolated in this survey differed from similar Phytophthora oak forest surveys in Europe in that $P$. cinnamomi was the most frequently encountered species. In Europe, $P$. quercina commonly was isolated in oak forest surveys $(3,4,19,24,27,31,33,49)$. The absence of $P$. quercina within our survey compared with European studies suggests a geographic limitation of this species to European oak forests. In oak forest studies conducted in Europe $(3,4,19,24,27,31$, $33,49)$ that were similar to our study, $P$. citricola, $P$. europaea, and $P$. cambivora also were present. Differences in species assemblage in European surveys compared with our survey mostly regard the occurrence of the unknown species: Phytophthora sp. 1, Phytophthora sp. 2, and $P$. quercina-like isolates. Species isolated in European oak forests $(3,4,19,24,27,31$, $33,49)$ but not isolated in our study included $P$. cactorum, $P$. cryptogea Pethybr. \& Lafferty, $P$. gonapodyides (Petersen) Buisman, $P$. megasperma Drechsler, $P$. pseudosyringae, $P$. psychrophila, and $P$. uliginosa. With the exception of $P$. gonapodyides, which is widely distributed in streams of hardwood forests in the southern Appalachian mountains (28), and $P$. cactorum, which was isolated from forest soils in the southeastern United States (13), none of the other species have been reported from oak forest soils in the eastern United States. Our isolation results on species assemblage are consistent with similar studies $(3,4,19,24,27,31,33,49$, $53,55)$, where usually only one species was isolated from a sampled site. We believe more species would have been isolated if a more intensive survey was conducted in a sampling area, including different sites with different vegetation types and microenvironments. In this study, as in European surveys, a few sample sites were chosen from a large sampling area (usually the sampling area was several hundred hectares). Therefore, the species assemblage

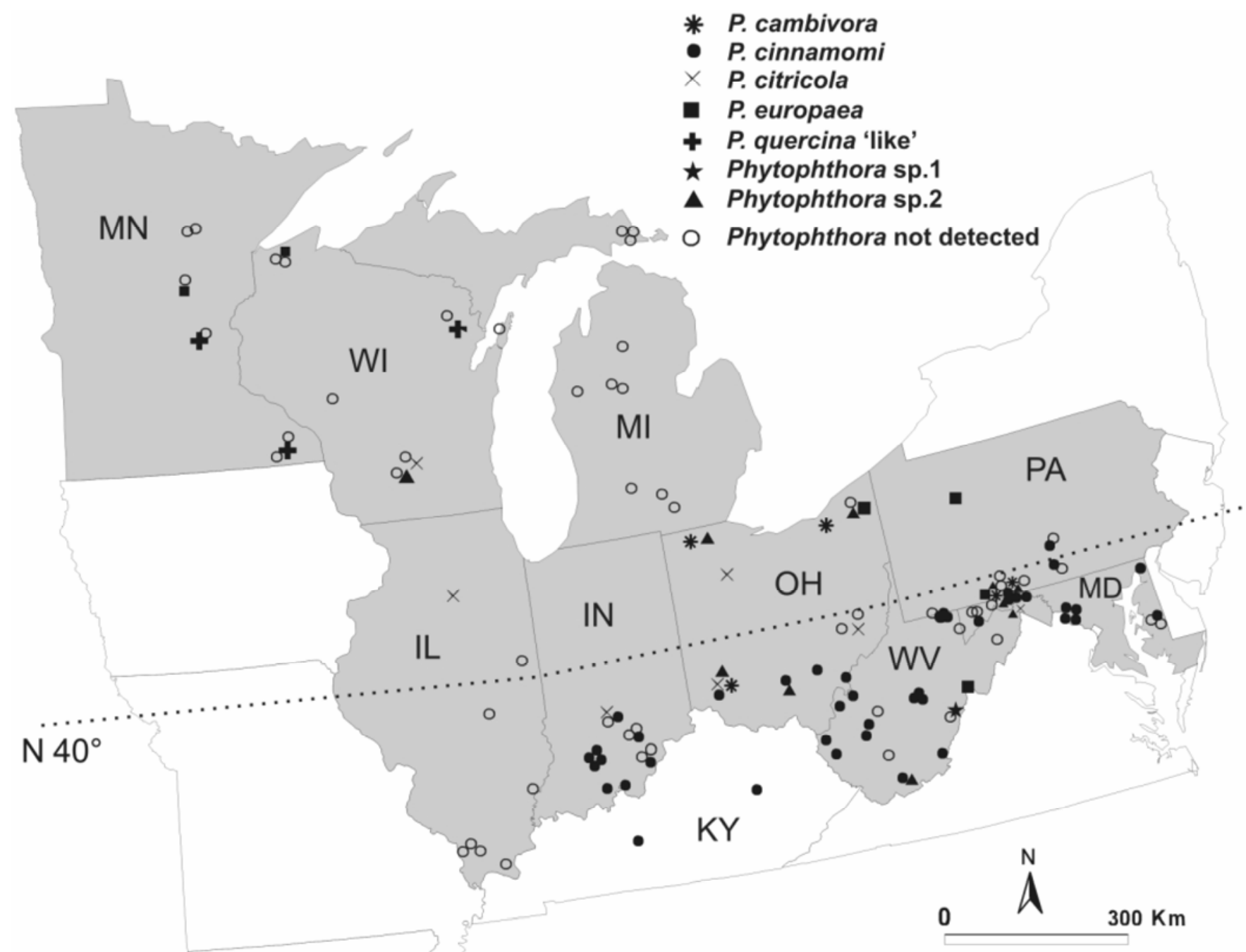

Fig. 1. Distribution of Phytophthora spp. isolated from soil throughout the survey area. 
in this study may represent the most common species present within the study area and may under-represent the species diversity because of the low intensity of this sampling.

P. cinnamomi is considered exotic to North America and is believed to have been introduced more then a century ago $(16,54)$. Whether this species suppressed the indigenous Phytophthora populations and thus resulted in higher isolation frequency is unknown. $P$. cinnamomi is widely distributed and is the most commonly isolated Phytophthora sp. in the southeastern United States and is extensively reported from forest soils, ornamental plant nurseries, and urban settings throughout the United States (13,16,20,21, 52,54,55). P. cinnamomi has been implicated as a factor in the littleleaf disease complex of pine trees (Pinus echinata and $P$. taeda), with root rot and mortality of sand pine plantations ( $P$. clausa) in west Florida, and with the death of American chestnut (Castanea dentata) in the southeastern United States $(5,16,46,54)$. The species also threatens the Christmas tree (Abies spp.) industry $(7,54)$. Phytophthora cinnamomi has been reported to be associated with bleeding cankers on $Q$. laurifolia in central Florida (52) and trunk cankers of Q. agrifolia and $Q$. suber in California (38). Its impact on oak trees under forest settings was shown in central Mexico on $Q$. glaucoides, $Q$. peduncularis, and $Q$. salicifolia (47) and in Europe on Q. rubra and $Q$. robur by its association with ink disease (41) and decline of $Q$. suber and $Q$. ilex $(10,39)$. Although the organism was widespread in our study, we found a significant association of $P$. cinnamomi only with declining $Q$. alba. We could not associate $P$. cinnamomi with declining $Q$. ru$b r a$, despite its frequent isolation from $Q$. rubra sites.

Our inability to isolate $P$. cinnamomi from forest soils above $40^{\circ} \mathrm{N}$ latitude could be due to low winter temperatures or other suppressive soil conditions that simply may be unfavorable for its survival. The current range of $P$. cinnamomi matched areas with an average annual minimum temperature greater than $-20^{\circ} \mathrm{C}$, which represents USDA plant hardiness zone $6 \mathrm{a}$ (15). The negative effect of low temperatures on $P$. cinnamomi populations $(6,51,54)$, the pattern of pathogen spread in Europe (11), and development of $P$. cinnamomi-induced cankers on $Q$. rubra and $Q$. robur (37) has been demonstrated; however, less is known about the effect of temperature on pathogen survival in soil. Areas with low soil temperature may have inhibited pathogen survival and, thus, restricted the spread of $P$. cinnamomi to other geographic areas. $P$. cinnamomi did not survive in upper soil layers but remained viable at depths below $10 \mathrm{~cm}$ after freezing temperatures in artificially inoculated soils (54). Similarly, cold winter temperatures inactivated $P$. cinnamomiinfested root segments of Abies fraseri in naturally infested soils when soil temperature dropped to $0^{\circ} \mathrm{C}$ or less (6). Furthermore, Roth and Huhlman (42) did not observe mortality of Douglas-Fir (Pseudotsuga menziesii) seedlings grown in Phytophthora cinnamomi infested soils when soil temperatures were lower than $15.5^{\circ} \mathrm{C}$. When compared with $P$. cinnamomi, the widespread occurrences of the other isolated Phytophthora spp. within the survey area suggest that they are better adapted to diverse environmental conditions such as temperature extremes.

Our data provides circumstantial evidence that supports an association between the presence of $P$. cinnamomi and declining $Q$. alba trees. Other studies also have demonstrated an association of Phytophthora spp. with declining oak trees in certain geographic areas $(4,33,49)$. However, the aim of this study was to examine the incidence of Phytophthora spp. in oak ecosystems rather than to examine their role. Because of the involvement of a variety of biotic and abiotic factors in any oak decline syndrome $(1,48)$, the association of Phytophthora spp. with crown condition ratings over a large survey area is not definitive evidence of a cause-and-effect relationship. Indeed, in some studies, no association was found with decline and frequency of Phytophthora spp. (3,14,19, 27,30,49).

P. citricola has a worldwide distribution and commonly was isolated in oak and chestnut ( $C$. sativa) stands in Europe $(3,4,19,24,33,49,50)$ and was isolated from trunk cankers on $Q$. agrifolia in natural oak woodlands in California and from streams in the southern Appalachian Mountains $(21,28,38)$. It has been suggested that this organism may form a species or subspecies complex which could be separated into genetically and morphologically distinct types $(1,12)$. Among the three $P$. citricola types identified in Austria and Turkey $(3,4)$, isolates obtained in this study matched the type A isolates. Pathogenicity of $P$. citricola isolates on various oak species has been demonstrated (Y. Balci, unpublished data; 4,8,32,38), but no relationship was observed in our study with declining oak trees.

P. europaea previously was isolated in oak forests in Austria, France, and Germany $(24,27,33)$. In the United States, this species has been isolated from leaves of bay laurel (Umbellularia californica) and stream water in California (D. Rizzo, personal communication), and Christmas tree plantation soils in Michigan (D. W. Fulbright, personal communication). Isolates from California and Michigan were identical in their morphology and internal transcribed spacer rDNA sequence analysis when compared with P. europaea isolates from this study (data not shown). Although its origin remains unknown, our findings suggest a much wider occurrence of this species in U.S. oak forests than in Europe (2).

P. cambivora was a commonly isolated species from European oak forest soils $(19,27,32,33)$, and often was associated with soil and cankers of chestnut trees (Castanea sp.) (49,50). This species also was isolated from forest soils in Argentina (23). In the United States, it was mostly recognized as causing crown and root rot of fruit trees (19) and, recently, was found in south-central Oregon in soils and basal cankers on chinquapin (Castanopsis sp.) (45). This species appears to be common in forest soils and has the ability to cause stem lesions on particular hosts, including Castanea and Fagus spp. (1). However, it has never been found in association with any aboveground cankers on oak trees.

The occurrence of a variety of wellknown as well as unknown isolates in oak forests of the eastern and north-central United States suggests that a diverse population of Phytophthora organisms exists. Their presence usually is not associated with symptoms on aboveground parts, although they may cause root damage. A time lag between factors may obscure the relationship between soilborne Phytophthora spp. and the initiation of aboveground decline symptoms. The existence and pathogenicity of exotic Phytophthora organisms in forest ecosystems likely are related to specific environmental conditions. As shown here for P. cinnamomi, the pathogen is widely distributed in diverse forest settings that favor its survival but not necessarily its virulence.

\section{ACKNOWLEDGMENTS}

This research was made possible by funding from the USDA-Forest Service Northeastern and Pacific Southwest Research Stations. We thank all state co-operators who were involved in site selection and soil sampling; A. Barker, an undergraduate laboratory assistant at WVU, and S. French, USDA Forest Service, St. Paul, MN, for their help with laboratory routines; M. E. Gallegly for providing his insight and isolates for comparisons; $G$. Luzader for generating the survey map; and the reviewers and the editor for making comments and suggestions which greatly improved the article.

\section{LITERATURE CITED}

1. Balci, Y. 2002. Phytophthora species in oak ecosystems in Austria and Turkey and their role in the oak decline syndrome. Ph.D. thesis, BOKU, Vienna, Austria.

2. Balci, Y., Balci, S., Eggers, J., MacDonald, W., Juzwik, J., Long, R., and Gottschalk, K. 2006. First report of Phytophthora europaea in oak forests in the eastern and north-central United States. Plant Dis. 90:827.

3. Balci, Y., and Halmschlager, E. 2003. Incidence of Phytophthora species in oak forests in Austria and their possible involvement in oak decline. For. Pathol. 33:157-174

4. Balci, Y., and Halmschlager, E. 2003. Phy tophthora species in oak ecosystems in Turkey and their association with declining oak trees. Plant Pathol. 52:694-702.

5. Barnard, E. L., Cordell, C. E., Gilly, S. P., and Kais, A. G. 1993. Comparative performance of sand and longleaf pines on a Phytophthora cinnamomi-infested sandhill in west Florida. 
South. J. Appl. For. 17:90-95.

6. Benson, D. M. 1982. Cold activation of Phytophthora cinnamomi. Phytopathology 72:560563

7. Benson, D. M., and Grand, L. F. 2000. Incidence of Phytophthora root rot of Fraser fir in North Carolina and sensitivity of isolates of Phytophthora cinnamomi to metalaxyl. Plant Dis. 84:661-664.

8. Bianco, M. C., Di Brisco, D., Luisi, N., and Lerario, P. 2002. Pathogenicity of Phytophthora species on Quercus seedlings. Pages 148-153 in: Phytophthora in Forests and Natural Ecosystems. 2nd Int. IUFRO Work. Party Meet., Albany, W. Australia. J. A. McComb, G. E. St. J. Hardy, and I. C. Tommerup, eds. Murdoch University Print. Perth, W. Australia.

9. Brasier, C. M., Beales, P. A., Kirk, S. A., Denman, S., and Rose, J. 2005. Phytophthora kernoviae sp. nov., an invasive pathogen causing bleeding stem lesion on forest trees and foliar necrosis of ornamentals in the UK. Mycol. Res. 109:853-859.

10. Brasier, C. M., Robredo, F., and Ferraz, J. F. P. 1993. Evidence for Phytophthora cinnamomi involvement in Iberian oak decline. Plant Pathol. 42:140-145

11. Brasier, C. M., and Scott, J. K. 1994. European oak declines and global warming: a theoretical assessment with special reference to the activity of Phytophthora cinnamomi. Bull. OEPP/EPPO Bull. 24:221-232.

12. Bunny, F. J. 1996. The biology, ecology and taxonomy of Phytophthora citricola in native plant communities in Western Australia. Ph.D. thesis. Murdoch University, Perth, W. Australia.

13. Campbell, W. A., and Hendrix, F. F. 1967. Pythium and Phytophthora species in forest soils in the southeastern United States. Plant Dis. Rep. 51:929-932.

14. Camy, C., Delatour, C., and Marçais, B. 2003. Relationship between soil factors, Quercus robur health, Collybia fusipes root infection and Phytophthora presence. Ann. For. Sci. 60:419426.

15. Cathey, H. M. 1990. USDA Plant hardiness zone map. U. S. Dep. Agric. Misc. Publ. No. 1475.

16. Crandall, B. S., Gravatt, G. F., and Ryan, M. M. 1945. Root disease of Castanea species and some coniferous and broadleaf nursery stocks, caused by Phytophthora cinnamomi. Phytopathology 35:162-180.

17. Davidson, J. M., Werres, S., Garbelotto, M., Hansen, E. M., and Rizzo, D. M. 2003. Sudden oak death and associated diseases caused by Phytophthora ramorum. Online. Plant Health Progress doi:10.1094/PHP-2003-0707-01-DG.

18. Davidson, J. M., Wickland, A. C., Patterson, H. A., Falk, K. R., and Rizzo, D. M. 2005. Transmission of Phytophthora ramorum in mixed evergreen forest in California. Phytopathology 95:587-596.

19. Delatour, C., 2003. Phytophthora in the European oak forest-results of a European Union research project. Pages 78-88 in: Phytophthora in Forests and Natural Ecosystems. 2nd Int. IUFRO Work. Party Meet., Albany, W. Australia. J. A. McComb, G. E. St. J. Hardy, and I. C. Tommerup, eds. Murdoch University Print.

20. Erwin, C. D., and Ribeiro, O. K. 1996. Phytophthora Diseases Worldwide. The American Phytopathological Society, St. Paul, MN.

21. Garbelotto, M., and Hüberli, D. 2006. First report on an infestation of Phytophthora cinnamomi in natural oak woodlands of California and its different impact on two native oak species. Plant Dis. 90:685.

22. Goheen, E. M., Hansen, E. M., Kanaskie, A., McWilliams, M. G., Osterbauer, N., and
Sutton, W. 2002. Sudden oak death, caused by Phytophthora ramorum, in Oregon. Plant Dis. 86:441.

23. Greslebin, A. G., Hansen, E. M., Winton, L. M., and Rajchenberg, M. 2005. Phytophthora species from declining Austrocedrus chilensis forests in Patagonia, Argentina. Mycologia 97:218-228.

24. Hansen, E. M., and Delatour, C. 1999. Phytophthora species in oak forests of north-east France. Ann. For. Sci. 56:539-547.

25. Hansen, E. M, Goheen, D. J., Jules, E. S., and Ullian, B. 1999. Managing Port-orford-cedar and the introduced pathogen Phytophthora lateralis. Plant Dis. 84:4-14.

26. Hansen, E. M., Reeser, P. W., Davidson, J. M., Garbelotto, M., Ivors, K., Douhan, L., and Rizzo, D. M. 2003. Phytophthora nemorosa a new species causing cankers and leaf blight of forest trees in California and Oregon, U.S.A. Mycotaxon 138:129-138.

27. Hartmann, G., and Blank, R. 2002. Occurrence and site relations of Phytophthora spp. in declining oak stands in north-western Germany. Forst Holzwirt 57:539-545.

28. Hwang, J. and Jeffers, S. 2005. Detection and identification of Phytophthora species in streams in the southern Appalachian mountains. (Abstr.) Phytopathology 95:S46.

29. Jeffers, S. N., and Aldwinckle, H. S. 1987. Enhancing detection of Phytophthora cactorum in naturally infested soil. Phytopathology 77:1475-1482.

30. Jonsson, U., Jung, T., Sonesson, K., and Rosengren, U. 2005. Relationships between health of Quercus robur, occurrence of Phytophthora species and site conditions in southern Sweden. Plant Pathol. 54:502-511.

31. Jonsson, U., Lundberg, L., Sonesson, K., and Jung, T. 2003. First records of soilborne Phytophthora species in Swedish oak forests. For. Pathol. 33:175-179.

32. Jung, T., Blaschke, H., and Neumann, P. 1996. Isolation, identification and pathogenicity of Phytophthora species from declining oak stands. Eur. J. For. Pathol. 26:253-272.

33. Jung, T., Blaschke H., and Oßwald, W. 2000. Involvement of soilborne Phytophthora species in Central European oak decline and the effect of site factors on the disease. Plant Pathol. 49:706-718.

34. Jung, T., Cooke D. E. L., Blaschke H., Duncan J. M., and Oßwald, W. 1999. Phytophthora quercina sp. nov., causing root rot of European oaks. Mycol. Res. 103:785-798

35. Jung T., Hansen E. M., Winton L., Oßwald, W., and Delatour, C. 2002. Three new species of Phytophthora from European oak forests. Mycol. Res. 106:397-411.

36. Jung, T., Nechwatal, J., Cooke, D. E. L., Hartmann, G., Blaschke, M., Oßwald, W., Duncan, J. M., and Delatour, C., 2003. Phytophthora pseudosyringae sp. nov., a new species causing root and collar rot of deciduous tree species in Europe. Mycol. Res. 107:772-789.

37. Marçais, B., Bergot, M., Perarnaud, V., Levy, A., and Desprez-Loustau, M. L. 2004. Prediction and mapping of the impact of winter temperature on the development of Phytophthora cinnamomi-induced cankers on red and pedunculate oak in France. Phytopathology 94:826831.

38. Mirchetich, S. M. Campbell, R. N., and Matheron, M. E. 1977. Phytophthora trunk canker of coast live oak and cork oak trees in California. Plant Dis. Rep. 61:66-70.

39. Moreira, A. C., Ferraz, J. F. P., and Clegg, J., 2000. The involvement of Phytophthora cinnamomi in cork and holm oak decline in Portugal. Pages 132-135 in: First Int. Meet. Phytophthoras For. Wildland Ecosyst. E. M.
Hansen and W. Sutton, eds. Grants Pass, OR

40. Rizzo, D. M., Garbelotto, M., Davidson J. M. Slaughter G. W., and Koike S. T. 2002. Phytophthora ramorum as the cause of extensive mortality of Quercus spp. and Lithocarpus densiflorus in California. Plant Dis. 86:205214.

41. Robin, C., Desprez-Loustau, M. L., Capron, G., and Delatour, C. 1998. First record of Phytophthora cinnamomi on cork and holm oaks in France and evidence of pathogenicity. Ann For. Sci. 55:869-883.

42. Roth, L. F., and Kuhlman, E. G. 1966. Phytophthora cinnamomi, an unlikely threat to Douglas-fir forestry. For. Sci. 12:147-159.

43. SAS. 2002. JMP Statistics and Graphics Guide: Version 5 SAS Institute, Inc., Cary, NC.

44. Shearer, B. L., and Tippett, J. T. 1989. Jarrah dieback: the dynamics and management of Phytophthora cinnamomi in the Jarrah (Eucalyptus marginata) forest of south-western Australia. CALM Res. Bull. No. 3

45. Sutton, W., and Hansen, E. M. 2003. Phy tophthoras in Oregon forests. Pages 274-275 in: Phytophthora in Forests and Natural Ecosystems. 2nd Int. IUFRO Work. Party Meet., Albany, W. Australia. J. A. McComb, G. E. St. J. Hardy, and I. C. Tommerup, eds. Murdoch University Print. Perth, W. Australia

46. Tainter, F. H., and Baker, F. A. 1996. Principles of Forest Pathology. John Wiley and Sons, New York.

47. Tainter, E., O’Brien, G. J., Hernandez, A. Orozco, F., and Rebolledo, O. 2000. Phytophthora cinnamomi as a cause of oak mortality in the State of Colima, Mexico. Plant Dis 84:394-398.

48. Thomas, F. M., Blank, R., and Hartmann, G 2002. Abiotic and biotic causes and their interaction as causes of oak decline in Central Europe. For. Pathol. 32:277-307.

49. Vettraino, A. M., Barzanti, G. P., Bianco, M C., Ragazzi, A., Capretti, P., Paoletti, E., Luisi, N., Anselmi, N., and Vannini, A. 2002. Occurrence of Phytophthora species in oak stands in Italy and their association with declining oak trees. For. Pathol. 32:19-28.

50. Vettraino, A. M., Morel, O., Perlerou, C Robin, C., Diamandis, S., and Vannini, A. 2005. Occurrence and distribution of Phytophthora species in European chestnut stands, and their association with ink disease and crown decline. Eur. J. Plant Pathol. 111:169180 .

51. Weste, G. 1983. Population dynamics and survival of Phytophthora. Pages 237-257 in Phytophthora. Its Biology, Taxonomy, Ecology and Pathology. D. C. Erwin, S. BartnickiGarcia, and P. H. Tsao, eds. American Phytopathological Society, St Paul, MN.

52. Wood, A. K., and Tainter, F. H. 2002. First report of Phytophthora cinnamomi on Quercus laurifolia. Plant Dis. 86:441.

53. Wood, A. K., Tainter, F. H., Jeffers, S. N., and Van Arsdel, E. P. 2003. Distribution of Phytophthora species in forest soils of upstate South Carolina, USA. Page 282 in: Phytophthora in Forests and Natural Ecosystems. 2nd Int. IUFRO Work. Party Meet., Albany, W. Australia. J. A. McComb, G. E. St. J. Hardy, and I. C. Tommerup, eds. Murdoch University Print. Perth, W. Australia.

54. Zentmyer, G. A., 1980. Phytophthora cinna $m o m i$ and the diseases it causes. Phytopathological Monograph 10. The American Phytopathological Society, St. Paul, MN.

55. Zwart, D. C., Jeffers, S. N., and Waldrop, T. A. 2004. Incidence of Phytophthora spp. in a hardwood forest site in the southern Appalachian Mountains. (Abstr.) Phytopathology 94:S118. 